\title{
Relationships between soil pH and base saturation - conclusions for Polish and international soil classifications
}

\begin{abstract}
Taking into account the fact that (a) measurement of the cation exchange capacity and base saturation is practically unavailable in the field, that formally makes impossible the reliable field classification of many soils, (b) base saturation is measured or calculated by various methods those results significantly differ, (c) base saturation and soil $\mathrm{pH}$ are highly positively correlated, it is suggested to replace the base saturation with $\mathrm{pH}_{\mathrm{w}}$ (measured in distilled/deionized water suspension) in the classification criteria for diagnostic horizons and soil units/subunits, both in the Polish Soil Classification and FAO-WRB. Based on statistical analysis of 4500 soil samples, the following $\mathrm{pH}_{\mathrm{w}}$ values are recommended instead of $50 \%$ base saturation: $\mathrm{pH}_{\mathrm{w}}<5.5$ for umbric and $\mathrm{pH}_{\mathrm{w}} \geq 5.5$ for the mollic horizon, and for Chernozems, Kastanozems, Phaeozems (directly) and Umbrisols (indirectly). Furthermore, the $\mathrm{pH}_{\mathrm{w}}$ $<4.7$ may feature the Dystric qualifier in mineral soils and respective Reference Soil Groups of WRB; while the $\mathrm{pH}_{\mathrm{w}} \geq 4.7$ may feature the Eutric qualifier. The distinction between subtypes of the brown soils in the Polish Soil Classification may base on the $\mathrm{pH}_{\mathrm{w}} 4.7$ or 5.0 , but using different requirements of $\mathrm{pH}$ distribution in the depth control section. The replacement of the base saturation with $\mathrm{pH}$ refers to the formal soil classification only, and does not exclude the use of base saturation for professional soil characteristics.
\end{abstract}

Keywords: base saturation, $\mathrm{pH}$, soil classification, WRB, Polish Soil Classification

\section{INTRODUCTION}

The saturation of soil cation exchange capacity (CEC) with exchangeable base cations, simplified to as "base saturation" (BS), has been considered a complex physicochemical parameter that approximates the relationships between exchangeable "basic" and "acidic" cations in relation to other soil properties and external factors, such as weathering stage, parent material origin, texture, organic matter content, climate, vegetation, fertilization, contamination etc. (Blosser and Jenny 1971, Gałka et al. 2014, Gruba and Mulder 2015, Bojko and Kabała 2016, Musielok and Drewnik 2016, Józefowska et al. 2017). As a direct measure, base saturation may indicate the behaviour and availability of crucial elements (Bloom et al. 2005, Bielińska and Mocek 2010). Therefore, BS became a general indicator of soil trophic status, presumed to be better than other single characteristics, including the $\mathrm{pH}$ value (Bieganowski et al. 2013, Kobierski et al. 2015, Łabaz et al. 2016), and thus became widely used in soil characterisation and classification as one of crucial diagnostic criteria (Kacprzak and Derkowski 2007, Mendyk et al. 2015, Świtoniak 2015, Kowalska et al. 2017, Krupski et al. 2017, Charzyński et al. 2018, Waroszewski et al. 2018).
However, CEC and BS cannot be measured in the field, due to special equipment necessary for analysis. Therefore, the reliable and final naming, classification and cartography of many soils is in fact impossible until the analytical data from the laboratory were delivered, that may take weeks. Such a prolonged lack of final decision is particularly inconvenient at soil mapping, where the contours of soil unit should be approximated during the field investigation (Brevik et al. 2016). The above mentioned problem is not marginal. Such a crucial diagnostic horizons as mollic and umbric, common qualifiers Eutric and Dystric, and reference groups Phaeozems, Alisols, Luvisols etc. include BS in their diagnostic criteria (IUSS Working Group WRB 2015). It means, many basic distinctions cannot be completed without advanced laboratory analysis. The formal requirements for diagnostic horizons/qualifiers do not allow a field approximation of BS of mineral soils based on their field-measured $\mathrm{pH}$, even if this approximation is commonly applied by many soil scientists. One can therefore conclude, that the classification of many soil units in the field is a fiction at present, if laboratory data are unavailable.

The other disadvantage of BS is variable methodology of its measurement. There is no universal extracting agent similarly effective in both the acid, 
neutral and alkaline soils; mineral and organic; rich or poor in carbonates, gypsum, and easily soluble salts (Ross et al. 2008). The methods developed over the century of investigation were suited to local climate and soil conditions, and to the particular needs (Sumner and Miller 1996). As the agriculture-oriented attempts prevailed in the studies on soil sorption and cation exchange phenomena, the standard methods refer to potential equilibrium state, at the target $\mathrm{pH}$ of 7.0 or 8.2, depending on local soil conditions (Schollenberger and Simon 1945, Maksimow and Góralski 1959). However, such attempt, theoretically and practically justified for the local optimization of the fertilization, is not acceptable in soil classification, where the universal criteria must be applied for all soils to avoid different classification of the same soil, depending on the method used for the analysis (Sumner and Miller 1996). Thus, most of the national soil classifications have accepted only one method of CEC and BS analysis, but not the same (Nemeček et al. 2001, Reintam and Köster 2006, Secu et al. 2008, Shi et al. 2010). As a result, a common, but hidden problem is a limited correlativity of national soil maps and databases merged within international programmes (Jones et al. 2005, Reintam and Köster 2006, Keesstra et al. 2016).

The international soil classification WRB (IUSS Working Group WRB 2015) requires two different methods of BS calculation:

(1) as a ratio of base cations (BC) to $\mathrm{CEC}_{7}$, where both $\mathrm{BC}$ and $\mathrm{CEC}_{7}$ are measured in the extract obtained after soil percolation with $\mathrm{NH}_{4} \mathrm{OAc}$ at $\mathrm{pH} 7$ in the glass pipes; applied to distinguish between mollic and umbric horizons, and to identify Chernozems, Kastanozems, Phaeozems, and, indirectly, Umbrisols; designated here $\mathrm{BS}_{7}$, and

(2) as a ratio of $\mathrm{BC}$ (measured in $\mathrm{NH}_{4} \mathrm{OAc}$ at $\mathrm{pH}$ 7) to so called effective cation exchange capacity $\left(\mathrm{ECEC}_{\mathrm{AL}}\right)$, i.e. the sum of $\mathrm{BC}$ and exchangeable aluminium (extracted with $1 \mathrm{M} \mathrm{KCl}$, unbuffered) - diagnostic for Eutric/Dystric qualifiers, and for Acrisols, Alisols, Lixisols, and, indirectly, also for Luvisols; designated here $\mathrm{BS}_{\mathrm{AL}}$.

This approach has been criticized as too complicated - requiring two measures for the same soil feature, even in one soil profile (e.g. in Gleysols, where different BS is applied to recognise the mollic/umbric horizons, if present, and the Eutric/Dystric qualifier).

The problem with BS in soil classification has also arisen in Poland since the classification based on diagnostic horizons has introduced $0.2 \mathrm{M} \mathrm{BaCl}_{2}$ to measure the "total exchangeable acidity" (PSC 2011). Unfortunately, the comparability of this extraction with the methods accepted in WRB classification has not been proven. Moreover, $\mathrm{BaCl}_{2}$ solution has never been widely used in Poland and the utility of archival data to classify soils using the new criteria is unknown. The most typically in Poland, $\mathrm{BS}_{\mathrm{TA}}$ was calculated as the ratio of $\mathrm{BC}$ (extracted with $1 \mathrm{M}$ $\mathrm{NH}_{4} \mathrm{Cl} \mathrm{pH} \mathrm{7.8-8.2)} \mathrm{to} \mathrm{the} \mathrm{sum} \mathrm{of} \mathrm{BC} \mathrm{and} \mathrm{total}$ ("hydrolytic") acidity (TA) extracted with $0.5 \mathrm{M}$ $\mathrm{Ca}(\mathrm{OAc})_{2}$ or $1 \mathrm{M} \mathrm{NaOAc}$ (Maksimow and Góralski 1959, Lityński et al. 1976, Weber et al. 2007, Jaworska et al. 2008, Kalembasa et al. 2011, Szewczyk et al. 2015). This concept of $\mathrm{ECEC}_{\mathrm{TA}}$ and $\mathrm{BS}_{\mathrm{TA}}$ was derived intentionally for arable soils (regularly limed and fertilized), and is known to underestimate the base saturation in acid forest soils (Kabała et al. 2013) by overestimating the total acidity (due to the raising the equilibrium to the level that does not and cannot occur in most forest soils). To get a more realistic view into the present $\mathrm{BS}$ in the acid soils, such as most of the forest soils under temperate humid climate, many authors suggested (Lityński et al. 1976 Leitgeb et al. 2013) to calculate $\mathrm{BS}_{\mathrm{EA}}$ as the ratio of $\mathrm{BC}$ in $\mathrm{NH}_{4} \mathrm{OAc}$ at $\mathrm{pH} 7$ extract to $\mathrm{ECEC}_{\mathrm{EA}}$ being a sum of $\mathrm{BC}$ and exchangeable acidity (EA) in $1 \mathrm{M}$ $\mathrm{KCl}$, or using exchangeable $\mathrm{Al}$ instead of EA. The popularity of the latter method comes from an assumption that $\mathrm{BS}_{\mathrm{EA}}$ below $50 \%$ automatically indicates the domination of exchangeable aluminium, that is known of its toxicity to plant roots (Pokojska 1986, Porębska et al. 2008).

To avoid the above mentioned inconsistency related to different methods of BS calculation, that are deeply rooted in the local pedological traditions and cannot be modified/unified within a short time period, and to allow the reliable soil classification in the field, it is postulated to replace the BS with $\mathrm{pH}$ value as diagnostic criterion. The aim of this work is to testify the correlation between soil $\mathrm{pH}$ and $\mathrm{BS}$ calculated using two methods commonly used in Poland, and to derive the threshold $\mathrm{pH}$ values respective to $50 \%$ level of base saturation.

\section{MATERIALS AND METHODS}

A database of 4500 mineral soil samples was compiled, representative for a wide collection of arable and forest soils (Luvisols, Cambisols, Planosols, Stagnosols, Gleysols, Retisols, Alisols, Phaeozems, Chernozems, Arenosols, Podzols, Leptosols, and Fluvisols) from SW Poland and, to a lesser extent, other regions of Poland (Kabała et al. 2016a). The collection included samples from all mineral genetic horizons, thus the presented relationships may differ from other reports, that based mainly on topsoil 
layers (Clark and Hill 1964, Blosser and Jenny 1971, Jaremko and Kalembasa 2014). Large variability of soil texture is involved, with predominance of sand, loamy sand, sandy loam, loam, and silt loam classes. Similarly, samples were featured by broad range of organic carbon content and soil pH (Table). All laboratory analyses were conducted in the fine earths $(<2 \mathrm{~mm})$, after sample drying, crushing, and sieving. Soil $\mathrm{pH}$ was measured potentiometrically, in the distilled water $\left(\mathrm{pH}_{\mathrm{w}}\right)$ and in $1 \mathrm{M} \mathrm{KCl}\left(\mathrm{pH}_{\mathrm{KCl}}\right)$ suspensions at soil:solution ratio 1:2.5 v/v. Soil organic carbon (SOC) was determined by dry combustion with spectrometric detection of released $\mathrm{CO}_{2}$ (CS-Matt 5500), after carbonate removal if present; or by wet oxidimetric method with an external heating, the so called Tyurin method. Exchangeable base cations (BC) were extracted with $1 \mathrm{M} \mathrm{NH} \mathrm{NH}_{4} \mathrm{OAc}$ at $\mathrm{pH} 7$ (soil:solution 1:40) and the concentration of $\mathrm{Ca}, \mathrm{Mg}$, $\mathrm{K}$, and $\mathrm{Na}$ cations was determined using ICP technique (Kabała and Karczewska 2017). An exchangeable acidity (EA) was extracted with unbuffered $1 \mathrm{M} \mathrm{KCl}$ (soil:solution 1:10) and titrated potentiometrically up to $\mathrm{pH}$ 7.8. Exchangeable aluminium was measured in the same extract by potentiometrical titration, indirectly, after aluminium precipitation using $\mathrm{NaF}$. Total ("hydrolytic") acidity (TA) was extracted with $0.5 \mathrm{M} \mathrm{Ca}(\mathrm{OAc})_{2}$ (soil:solution $1: 10$ ) and titrated potentiometrically up to $\mathrm{pH} 7.8$ (Kabała and Karczewska 2017). Base saturation was calculated in three ways:

(1) using the exchangeable aluminium to calculate the aluminium-effective cation exchange capacity: $\mathrm{BS}_{\mathrm{AL}}[\%]=\mathrm{BC} * 100 / \mathrm{ECEC}_{\mathrm{AL}}$, where $\mathrm{ECEC}_{\mathrm{AL}}=\mathrm{BC}+$ exchangeable aluminium;

(2) using the exchangeable acidity (EA) to calculate the effective cation exchange capacity:

$\mathrm{BS}_{\mathrm{EA}}[\%]=\mathrm{BC} * 100 / \mathrm{ECEC}_{\mathrm{EA}}$,

where $\mathrm{ECEC}_{\mathrm{EA}}=\mathrm{BC}+\mathrm{EA}$;
(3) using the total ("hydrolytic") acidity (TA) to calculate the "total" cation exchange capacity: $\mathrm{BS}_{\mathrm{TA}}[\%]=\mathrm{BC} * 100 / \mathrm{CEC}_{\mathrm{TA}}$,

where $\mathrm{CEC}_{\mathrm{TA}}=\mathrm{BC}+\mathrm{TA}$.

The database has been completed over the years using the results of variably focused projects using different analytical protocols for particular samples. Thus, the number of samples used for particular correlation may greatly differ. It is displayed in Table, separately for each soil characteristics.

As the values of $\mathrm{pH}$ measured in distilled water and $1 \mathrm{M} \mathrm{KCl}$ are highly correlated in Polish soils (Kabała et al. 2016a), the modelling of the relationship between $\mathrm{pH}$ and BS was made in this study for the $\mathrm{pH}_{\mathrm{w}}$ only, and $\mathrm{pH}_{\mathrm{w}}$ was selected due to two technical circumstances: (a) field tests of soil $\mathrm{pH}$ are conducted in water suspension as a standard, both using the rapid potentiometric measurements and indication dyes, including the Hellige test (Steinhardt and Mengel 1981), and (b) distilled/deionised water is elsewhere available, including most petrol stations, that allows its easy gaining in case of exhaustion during field work.

Basic statistical parameters, correlation coefficients, and regression equations were calculated using the Statistica 12 package, whereas the fitting of mathematical models - using the CurveExpert Pro 2.5 (Hyams Development).

\section{RESULTS}

Mean total ("hydrolytic") acidity was nearly twofold higher than mean exchangeable acidity (Table); however, the difference between acidities decreased with increasing acidity values (Figure 1). Despite relatively high determination coefficient $\left(\mathrm{r}^{2}=0.70\right)$, huge variability of respective acidity values should be noted. For example, at the total acidity of 20 cmol(+) $\mathrm{kg}^{-1}$, soils had the exchangeable acidity in a

TABLE. Summary statistical characteristic of the soils used for calculations and correlations

\begin{tabular}{|c|c|c|c|c|c|c|c|c|c|c|}
\hline \multirow[t]{3}{*}{ Value } & \multirow[t]{3}{*}{$\mathrm{pH}_{\mathrm{w}}$} & \multirow[t]{3}{*}{$\mathrm{pH}_{\mathrm{KCl}}$} & \multirow[t]{2}{*}{$\mathrm{SOC}$} & \multirow{2}{*}{$\begin{array}{l}\text { Sum of } \\
\text { base } \\
\text { cations } \\
\text { B }\end{array}$} & \multirow[t]{2}{*}{$\mathrm{Al}_{\mathrm{ex}}$} & \multirow{2}{*}{$\begin{array}{l}\text { Echangeable } \\
\text { acidity }\end{array}$} & \multirow{2}{*}{$\begin{array}{l}\text { Total } \\
\text { acidity }\end{array}$} & \multicolumn{3}{|c|}{ Base saturation } \\
\hline & & & & & & & & $\mathrm{BS}_{\mathrm{AL}}$ & $\mathrm{BS}_{\mathrm{EA}}$ & $\mathrm{BS}_{\mathrm{TA}}$ \\
\hline & & & $\%$ & $\operatorname{cmol}(+)$ & & & & $\%$ & & \\
\hline $\mathrm{N}$ & 4580 & 4580 & 4210 & 3480 & 3600 & 4130 & 3070 & 2900 & 3480 & 2150 \\
\hline Mean & 4.9 & 4.2 & 2.7 & 3.7 & 2.5 & 3.6 & 6.5 & 51.4 & 43.0 & 31.5 \\
\hline Minimum & 2.9 & 2.1 & 0.03 & 0.05 & 0.0 & 0.0 & 0.0 & 1.6 & 1.6 & 1.1 \\
\hline Maximum & 8.3 & 7.7 & 17.8 & 85.0 & 22.1 & 28.4 & 70.0 & 100 & 100 & 100 \\
\hline SD & 0.9 & 0.9 & 2.8 & 6.8 & 3.3 & 3.9 & 7.0 & 31.8 & 29.8 & 27.2 \\
\hline
\end{tabular}

Explanation: $\mathrm{Al}_{\mathrm{ex}}$ - exchangeable aluminium, $\mathrm{N}$ - number of cases under investigation, $\mathrm{SOC}$ - soil organic carbon, $\mathrm{SD}-\mathrm{standard}$ deviation. 


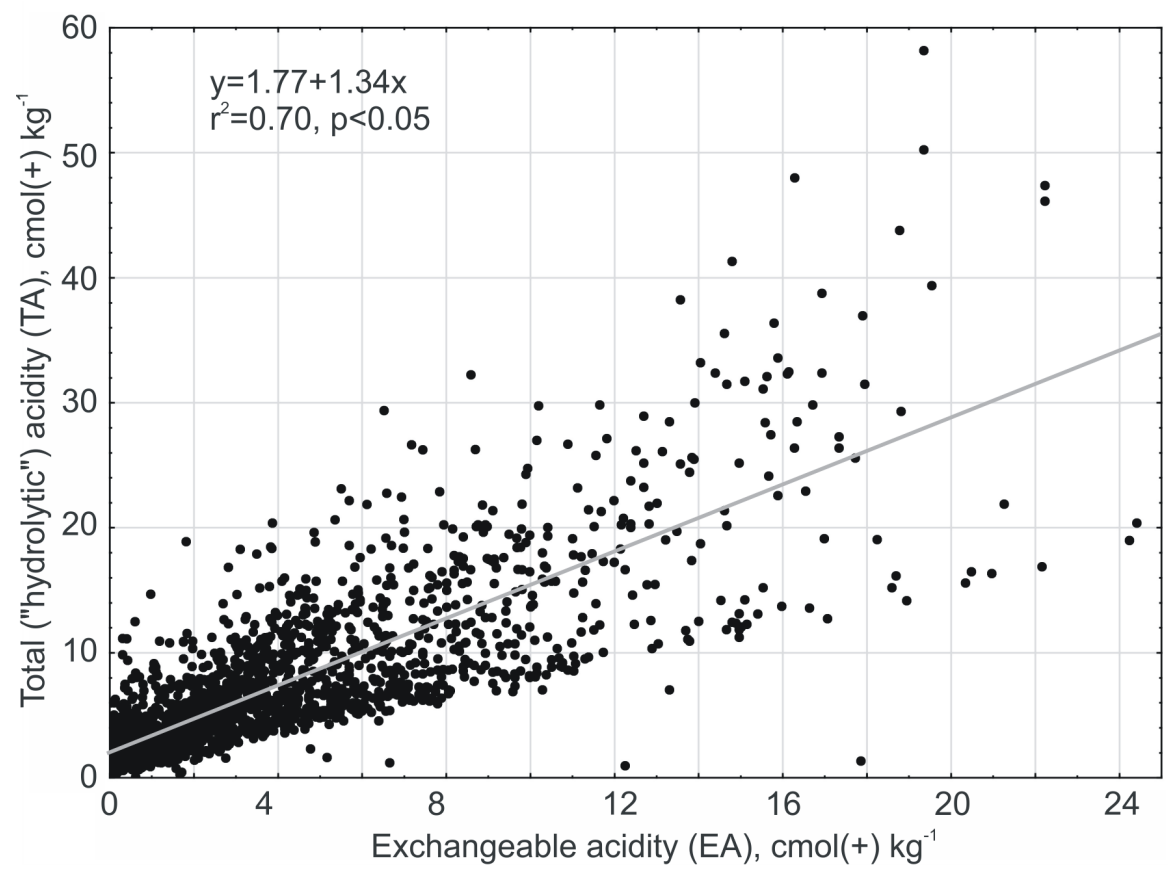

FIGURE 1. Relationships between exchangeable (EA) and total (TA) acidity in soils under investigation $(\mathrm{N}=3070)$.

broad range of $4-25 \mathrm{cmol}(+) \mathrm{kg}^{-1}$. This is probably a result of high content of $\mathrm{pH}$-dependent charge as typical for some humus- and iron oxide-rich soils, that may produce unexpectedly high potential acidity, if buffered salt was used to acidity extraction (Bloom et al. 2005). Despite the opinions on insignificant contribution of exchangeable hydrogen to exchangeable acidity as compared to exchangeable aluminium in mineral soils (Sumner et al. 1996, Leitgeb et al. 2013), the exchangeable aluminium created only ca. $70 \%$ of exchangeable acidity, on average (Table). This difference confirms the importance of $\mathrm{pH}$ dependent charge of soil organic matter (Bloom et al. 2005). If the mean values of exchangeable aluminium and acidity differ, also the difference may be expected in the $\mathrm{pH}$ value respective to $50 \%$ base saturation calculated using these two parameters.

Both EA and TA were highly positively correlated with $\mathrm{pH}_{\mathrm{w}}$; however, the relationships were non-linear, with many outliers (Figure 2), in particular at $\mathrm{pH}_{\mathrm{w}}$ values below 5 . One of differences between EA and TA was the $\mathrm{pH}$ level, at which acidity dropped to zero. Only the single samples have EA $>1 \mathrm{cmol}(+) \mathrm{kg}^{-1}$ at $\mathrm{pH}_{\mathrm{w}} \leq 6$ and EA practically dropped to zero at $\mathrm{pH}_{\mathrm{w}}>6.5$. Whereas in case of TA, many samples have TA $>1$ cmol(+) $\mathrm{kg}^{-1}$ even at $\mathrm{pH}_{\mathrm{w}}>7$, and TA decreased to zero level in apparently alkaline samples, i.e. at $\mathrm{pH}_{\mathrm{w}}>8$ (Figure 2). The latter statements have direct link to the relationships between $\mathrm{pH}_{\mathrm{w}}$ and $\mathrm{BS}$ calculated using EA or TA, as part of $\mathrm{ECEC}_{\mathrm{EA}}$ or $\mathrm{CEC}_{\mathrm{TA}}$, respectively (Figure 3 ). Some TA was found even in slightly alkaline soils containing carbonates, that was the case of soils developed from calcareous materials in the Pieniny Mts (Kowalska et al. 2017).
Relationship between $\mathrm{pH}$ and base saturation was non-linear irrespectively of the way of BS calculation (Figure 3). Even if some authors suggested a linear or near-linear trends in particular sections of $\mathrm{pH}-\mathrm{BS}$ relationship (Clark and Hill 1964, Blosser and Jenny 1971), a direct fitting of the whole data set to nonlinear model seems more reliable solution. Among numerous tested equations, the Richards Sigmoidal Model (for $\mathrm{pH}_{\mathrm{w}}$ and $\mathrm{BS}_{\mathrm{AL}}$ relationship) and the Morgan-Mercer-Flodin Sigmoidal Model (MMF), for all tested relationships, got the best fit to original data, confirmed by the highest values of determination coefficient, i.e.:

- for the relationship between $\mathrm{BS}_{\mathrm{AL}}$ (Richards Model)

$$
\mathrm{BS}_{\mathrm{AL}}=100 /\left(1+\mathrm{e}^{19.8-3.5^{*} \mathrm{x}}\right)^{0.2}, \mathrm{r}^{2}=0.50 \text {, }
$$

- for the relationship between $\mathrm{BS}_{\mathrm{EA}}$ and $\mathrm{pH}_{\mathrm{w}}(\mathrm{MMF}$ Model)

$$
\begin{aligned}
& \mathrm{BS}_{\mathrm{EA}}=\left(20.5^{*} 2336067241+102 * \mathrm{x}^{13}\right) / \\
& \left(2336067241+\mathrm{x}^{13}\right), \mathrm{r}^{2}=0.71,
\end{aligned}
$$

- for the relationship between $\mathrm{BS}_{\mathrm{TA}}$ and $\mathrm{pH}_{\mathrm{w}}(\mathrm{MMF}$ Model)

$$
\begin{aligned}
& \mathrm{BS}_{\mathrm{TA}}=\left(3.2 * 602147+104 * \mathrm{x}^{8}\right) /\left(602147+\mathrm{x}^{8}\right), \\
& \mathrm{r}^{2}=0.66 .
\end{aligned}
$$

where $\mathrm{x}$ is a $\mathrm{pH}_{\mathrm{w}}$ value.

The $\mathrm{pH}_{\mathrm{w}}$ values related to $50 \%$ base saturation were approximated based on above mentioned equations to the values of $\mathrm{pH}_{\mathrm{w}} 4.7,5.0$, and 5.4 for $\mathrm{BS}_{\mathrm{AL}}, \mathrm{BS}_{\mathrm{EA}}$, and $\mathrm{BS}_{\mathrm{TA}}$, respectively (Figure 3). However, large variability must be stressed ("cloud" of results), even if the determination coefficients got satisfactory levels. In particular, the broad "foot" was evident in all graphs (Figure 3), including large number of soils featured by very low $\mathrm{BS}$ in a $\mathrm{pH}_{\mathrm{w}}$ range of 4-5. 

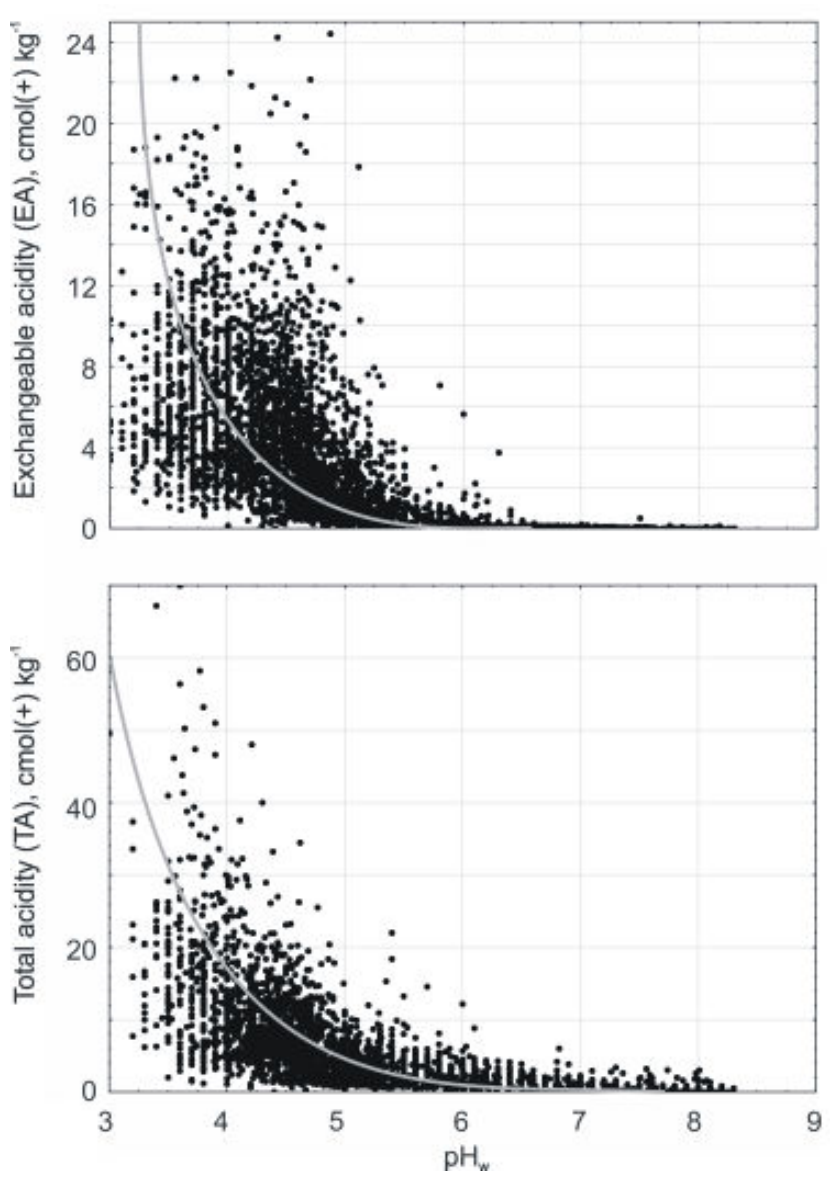

FIGURE 2. Relationships between $\mathrm{pH}_{\mathrm{w}}$ and exchangeable (EA) or total (TA) acidity in soils under investigation $(\mathrm{N}=4130$ and $\mathrm{N}=3070$, respectively)

FIGURE 3. Relationships between $\mathrm{pH}_{\mathrm{w}}$ and base saturation calculated using the exchangeable aluminium $\left(\mathrm{BS}_{\mathrm{AL}}\right)$ exchangeable acidity $\left(\mathrm{BS}_{\mathrm{EA}}\right)$ or total/hydrolytic acidity $\left(\mathrm{BS}_{\mathrm{TA}}\right)$

in a full range of soil $\mathrm{pH}(\mathrm{N}=2900, \mathrm{~N}=3480$, and $\mathrm{N}=2150$, respectively)

\section{DISCUSSION}

The $\mathrm{CEC}_{\mathrm{TA}}$, relatively simple and inexpensive in analytical terms, calculated as a sum of $\mathrm{BC}$ and TA, became popular in Poland after confirmation of its general comparability with more laborious and expensive $\mathrm{CEC}_{7}$, measured by soil leaching with $\mathrm{NH}_{4} \mathrm{OAc} \mathrm{pH} 7$ in glass columns (Lityński et al. 1976). Therefore, by analogy, the $\mathrm{BS}_{\mathrm{TA}}$ is believed comparable with $\mathrm{BS}_{7}$ (Gruba and Mulder 2015). If we accept this assumption, the $\mathrm{pH}_{\mathrm{w}}$ value 5.4 at which $\mathrm{BS}_{\mathrm{TA}}$ reached $50 \%$, may be considered appropriate to distinguish between mollic and umbric horizons, as related to the requirements of WRB (IUSS Working Group WRB 2015), Soil Taxonomy (Soil Survey Staff

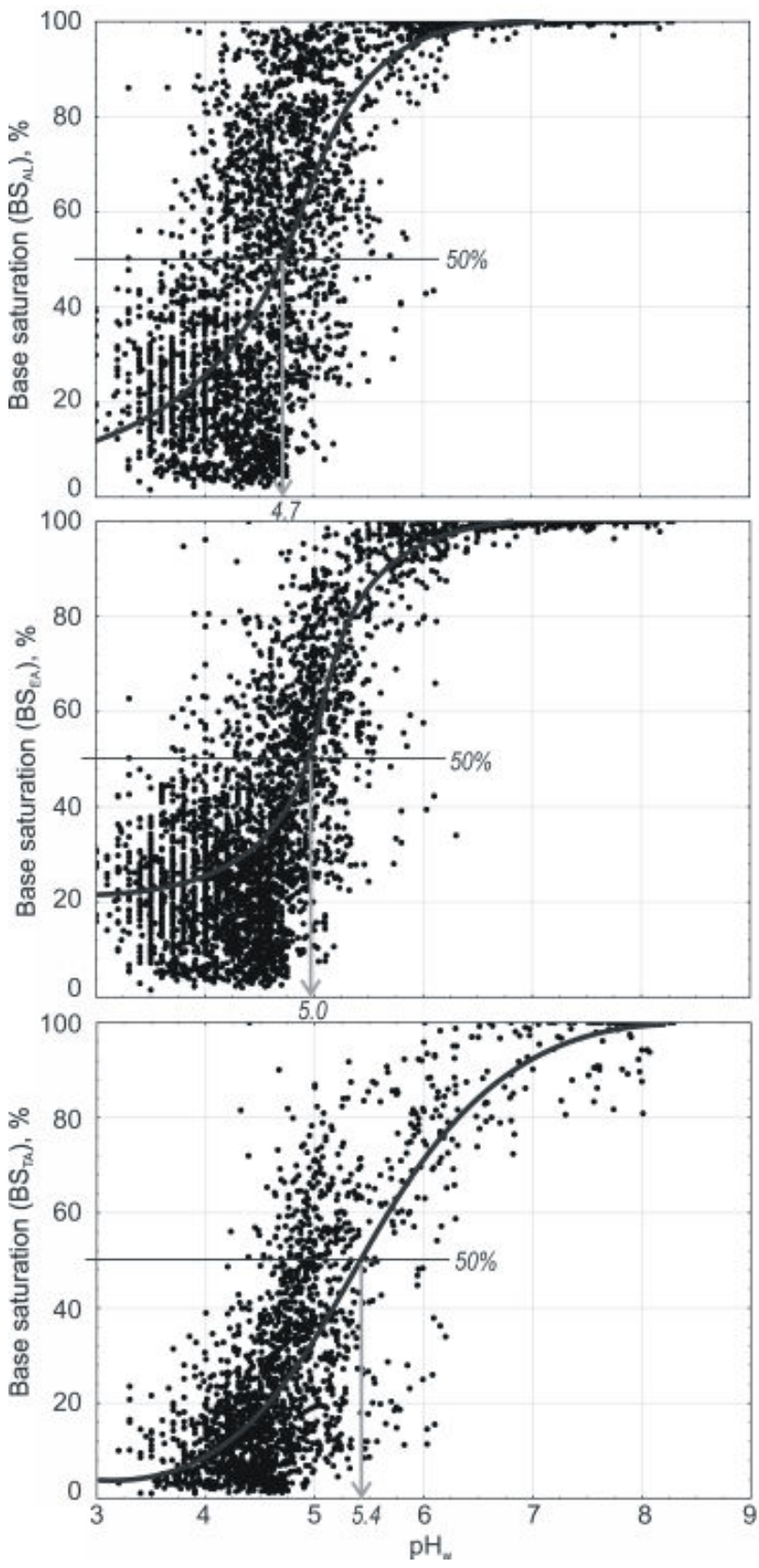

2014), and also Polish Soil Classification (PSC 2011). The threshold value must be disjunctive as a quantitative requirement, thus the rounded value of $\mathrm{pH}_{\mathrm{w}} \leq 5.5$ is recommended for mollic, whereas $\mathrm{pH}_{\mathrm{w}}<5.5$ for umbric horizon. In the same way, the $\mathrm{pH}_{\mathrm{w}} \leq 5.5$ is recommended where the $\mathrm{BS}_{7} \geq 50 \%$ is required, i.e. in Phaeozems, Chernozems and Kastanozems (IUSS Working Group WRB 2015).

Similarly, the $\mathrm{pH}_{\mathrm{w}}$ value of 4.7 , at which $\mathrm{BS}_{\mathrm{AL}}$ reached $50 \%$ level, may be considered appropriate for distinguishing between Eutric and Dystric qualifiers, i.e. $\mathrm{pH}_{\mathrm{w}}<4.7$ for Dystric and $\mathrm{pH}_{\mathrm{w}} \leq 4.7$ for Eutric qualifiers, prevailing in a $20-100 \mathrm{~cm}$ soil layer, respectively to original requirements (IUSS Working Group WRB 2015). Suggested threshold 
refers to mineral soils only. The organic materials (e.g. peat, litter) are unsatisfactory represented in a database under analysis. However, the $\mathrm{pH}_{\mathrm{w}}$ values related to $50 \% \mathrm{BS}$, calculated for limited number of organic samples, are in the range 5.3-5.5, that confirm the rightness of $\mathrm{pH}_{\mathrm{w}}$ value 5.5 already used to distinguish between Dystric and Eutric qualifiers in the organic materials (IUSS Working Group WRB 2015).

Bridging the quantitative criteria of WRB system (IUSS Working Group WRB 2015) and the Polish Soil Classification (PSC 2011), and also the Classification of Forest Soils of Poland (Klasyfikacja gleb leśnych Polski 2000), the $\mathrm{pH}_{\mathrm{w}}<5.5$ is suggested to feature the umbric, while $\mathrm{pH}_{\mathrm{w}} \leq 5.5$ - the mollic horizon, instead of $50 \%$ base saturation. Furthermore, the $\mathrm{pH}_{\mathrm{w}}$ value $\leq 5.5$ may be used as supplementary criterion for black earths, in Poland correlated with Phaeozems or Chernozems (Kabała et al. 2016b). The above suggested $\mathrm{pH}_{\mathrm{w}}$ threshold was tested using the recently published and easily available sources containing complete soil data, including the Soil Sequences Atlas II (Świtoniak and Charzyński 2018), the papers of Świtoniak (2015), Labaz and Kabala (2016), and Łabaz et al. (2018). The recognition of horizon or $\mathrm{RSG}$ based on $\mathrm{pH}_{\mathrm{w}}$ differed from the original classification based on base saturation in 2 of 47 soil cases/profiles only.

The implementation of criteria for dystric/eutric characteristic in Polish soil classifications is more complex. First, dystric/eutric qualifiers do not have direct equivalents in PSC (2011). The eutrophic/dystrophic characteristic of soil is applied at type or subtype level specifically for brown soils and vertisols only (Cambisols and Vertisols, respectively, according to Kabała et al. 2016b). Moreover, not two, but three subtypes of brown soils are traditionally distinguished in Poland, i.e. proper - leached - acid (Classification of Forest Soils 2000) or eutrophic - leached - dystrophic (PSC 2011). Furthermore, in Polish classifications, the particular BS (e.g. $<50 \%$ for dystrophic/acid brown soils) is required in the entire depth control section (between 30 and $80 \mathrm{~cm}$, or 20 and $100 \mathrm{~cm}$ ), whereas in WRB, the qualifier Dystric refers to $\mathrm{BS}<50 \%$ prevailing in a depth control section (between 20 and $100 \mathrm{~cm}$ ). And the last, BS has never been calculated in Poland as $\mathrm{BS}_{\mathrm{AL}}$ (as WRB requires for Dytric/Eutric qualifiers) even in acid forest soils, but using the "hydrolytic" or exchangeable acidity (Gałka et al. 2013, 2014; Bojko and Kabala 2016). Taking into account the above mentioned circumstances, all three thresholds $\left(\mathrm{pH}_{\mathrm{w}}\right.$ values 4.7 , 5.0 and 5.5) were tested using the examples of brown soils (Cambisols) published in the Atlas of Forest Soils (Brożek and Zwydak 2003). The distinction made at
$\mathrm{pH}_{\mathrm{w}} 5.5$ (derived from a large database of various soils, not only brown soils/Cambisols) led to significant underestimation of proper/eutrophic brown soils, thus identified as leached or acid/dystrophic brown soils, even in the forest habitats characterised as "hypertrophic". Conversely, the threshold at $\mathrm{pH}_{\mathrm{w}} 4.7$, applied to entire depth control section $20-100 \mathrm{~cm}$, led to a conversion of some acid brown soils into leached brown soils subtype. However, if the classification applied the $\mathrm{pH}_{\mathrm{w}}<4.7 / \geq 4.7$ to the prevailing part of the depth control section (following the rules of WRB classification), the differences between "old" and "new" soil names/classifications were minimal (in 2 of 34 profiles). Also the allocation of soil profiles into dystrophic and eutrophic (proper and leached) groups of brown soils was nearly identical with the allocation into Dystric and Eutric qualifiers of WRB. A reconsidering of the brown soils presented in the Atlas (Brożek and Zwydak 2003) using the $\mathrm{pH}_{\mathrm{w}}<5.0 /$ $\geq 5.0$ as a threshold value (applied to the entire control section $20-100 \mathrm{~cm}$ for the acid and proper brown soils, respectively) led to single changes in Polish names of soils and single incompatibilities with the names derived from WRB. It was, therefore, concluded, that both the $\mathrm{pH}_{\mathrm{w}} 5.0$ and 4.7 may be alternatively used as threshold value to differentiate the subtypes of brown soilsbrown soils in the Polish Soil Classification; however, different $\mathrm{pH}$ distribution requirements must be applied within the depth control section:

(1) $\mathrm{pH}_{\mathrm{w}} 4.7$ as a threshold:

- proper brown soils $-\mathrm{pH} \leq 4.7$ throughout the entire control section $(20-100 \mathrm{~cm})$,

- leached brown soils $-\mathrm{pH} / 4.7$ in the prevailing part of the control section,

- acid brown soils $-\mathrm{pH}<4.7$ in the prevailing part of the control section; or

(2) $\mathrm{pH}_{\mathrm{w}} 5.0$ as a threshold:

proper brown soils $-\mathrm{pH} \leq 5.0$ throughout the entire control section $(20-100 \mathrm{~cm})$,

- leached brown soils $-\mathrm{pH}<5$ in any part (sublayer) of the control section,

acid brown soils $-\mathrm{pH}<5.0$ throughout the entire control section.

It seems that the suggested conversion of BS into $\mathrm{pH}$ as the diagnostic criteria for key horizons and soil units may significantly decrease the costs of the soil classification and cartography. In many countries, including Poland, the simplification of criteria may enlarge the acceptance for modern soil classification.

Also, this must be clearly stated, that above mentioned recommendations refer to the formal soil classification only, and do not exclude the further use of base saturation for soil characteristic and diagnosis, e.g. for evaluation of the trophic soil varieties, 
following the methodology of SIG - Soil Trophic Index (Brożek et al. 2015). The same refers to exchangeable acidity (including exchangeable aluminium) and total ("hydrolytic") acidity as popular and valuable soil characteristics, used for professional analysis of soil cation exchange phenomena, calculation of fertilization or liming needs, soil degradation, etc. (Gałka et al. 2013). Cation exchange capacity still must be analysed if low activity clays are present in soil and very CEC is expected, to identify the Ferralsols, Lixisols, and Acrisols.

\section{CONCLUSIONS}

Taking into account the fact that (a) measurement of the cation exchange capacity and base saturation is practically unavailable in the field, that formally makes impossible the reliable field classification of many soil units, (b) base saturation is measured or calculated using various methods those results significantly differ, (c) base saturation and soil $\mathrm{pH}$ are highly positively correlated, it is suggested to replace the base saturation with $\mathrm{pH}_{\mathrm{w}}$ (measured in distilled/ deionized water suspension) in the classification criteria for diagnostic horizons and soil units/subunits.

Based on statistical analysis of some 4500 soil samples, the following $\mathrm{pH}_{\mathrm{w}}$ values are recommended instead of $50 \%$ base saturation (both in the Polish and WRB soil classifications): $\mathrm{pH}_{\mathrm{w}}<5.5$ for umbric, and $\mathrm{pH}_{\mathrm{w}} \leq 5.5$ for mollic horizon and for Phaeozems, Chernozems, Kastanozems (directly), and Umbrisols (indirectly). Furthermore, the $\mathrm{pH}_{\mathrm{w}}<4.7$ may replace $50 \%$ base saturation for the Dystric qualifier in mineral soils and as criterion for Alisols, while $\mathrm{pH}_{\mathrm{w}} \leq 4.7$ may feature the Eutric qualifier (and Luvisols, indirectly). Both the $\mathrm{pH}_{\mathrm{w}} 4.7$ and 5.0 may be applied to distinguish between eutrophic - leached - dystrophic (or proper-leached - acid) brown soils in Polish soil classification, but using different requirements for $\mathrm{pH}$ distribution throughout the depth control section.

\section{REFERENCES}

Bieganowski A., Witkowska-Walczak B., Gliński J., Sokołowska Z., Sławiński C., Brzezińska M., Włodarczyk T., 2013. Database of Polish arable mineral soils: a review. International Agrophysics 27(3): 335-350.

Bielińska E.J., Mocek A., 2010. Właściwości sorpcyjne i aktywność enzymatyczna gleb parków miejskich na terenach o zróżnicowanym wpływie antropopresji. Journal of Research and Applications in Agricultural Engineering 55(3): 20-23 (in Polish with English abstract).

Bloom P.R., Skyllberg U.L., Sumner M.E., 2005. Soil acidity. [In:] Tabatai M.A. and Sparks D.L. (Eds) Chemical processes in soils, SSSA Book Series, Madison, Wisconsin: 411-459.
Blosser D.L., Jenny H., 1971. Correlations of Soil pH and Percent Base Saturation as Influenced by Soil-Forming Factors. Soil Science Society of America Journal 35(6): 1017-1018.

Bojko O., Kabala C., 2016. Transformation of physicochemical soil properties along a mountain slope due to land management and climate changes - a case study from the Karkonosze Mountains, SW Poland. Catena 140: 43-54.

Brevik E.C., Calzolari C., Miller B.A., Pereira P., Kabala C., Baumgarten A., Jordán A., 2016. Soil mapping, classification, and pedologic modeling: History and future directions. Geoderma 264: 256-274

Brożek S., Lasota J., Błońska E., Wanic T., Zwydak M., 2015. Waloryzacja siedlisk obszarów górskich na podstawie Siedliskowego Indeksu Glebowego (SIGg). Sylwan 159: 684 (in Polish with English abstract).

Brożek S., Zwydak M., 2003. Atlas gleb leśnych Polski. Centrum Informacyjne Lasów Państwowych, Warszawa: 467 pp.

Charzyński P., Bednarek R., Hudańska P., Świtoniak M., 2018. Issues related to classification of garden soils from the urban area of Toruń, Poland. Soil Science and Plant Nutrition 64(2): 132-137.

Clark J.S., Hill R.G., 1964. The pH-percent base saturation relationships of soils. Soil Science Society of America Journal 28(4): 490-492.

Gałka B., Podlaska M., Kabała C., 2013. Forest habitats on dystric Cambisols developed from granite in the Stołowe Mountains. Sylwan 157(5): 385-394.

Gałka B., Kabała C., Łabaz B., Bogacz A., 2014. Influence of stands with diversed share of Norway spruce in species structure on soils of various forest habitats in the Stołowe Mountains. Sylwan 158(9): 684-694.

Gruba P., Mulder J., 2015. Tree species affect cation exchange capacity (CEC) and cation binding properties of organic matter in acid forest soils. Science of the Total Environment 511: $655-662$.

IUSS Working Group WRB, 2015. World Reference Base for Soil Resources 2014, Update 2015. International soil classification system for naming soil and creating legends for soil maps. Food and Agriculture Organization of the United $\backslash$ Nations, Rome: 186 pp.

Jaremko D., Kalembasa D., 2014. A comparison of methods for the determination of cation exchange capacity of soils. Ecological Chemistry and Engineering, S, 21(3): 487-498.

Jaworska H., Kobierski M., Dąbkowska-Naskręt H., 2008. Kationowa pojemność wymienna i zawartość kationów wymiennych w glebach płowych o zróżnicowanym uziarnieniu. Soil Science Annual - Roczniki Gleboznawcze 59(1): 84-89 (in Polish with English abstract).

Jones A., Montanarella L., Jones R., 2005. Soil atlas of Europe. European Commission: $126 \mathrm{pp}$.

Józefowska A., Pietrzykowski M., Woś B., Cajthaml T., Frouz J., 2017. The effects of tree species and substrate on carbon sequestration and chemical and biological properties in reforested post-mining soils. Geoderma 292: 9-16.

Kabała C., Bogacz A., Gałka B., Jezierski P., Łabaz B., Waroszewski J., 2013. Cation exchange capacity of soils developed on various bedrock in the Stolowe Mountains. Prace Geograficzne 135: 7-20.

Kabała C., Karczewska A., 2017. Metodyka analiz laboratoryjnych gleb i roślin, wydanie 8 . INoGOŚ, UP Wrocław. http://karnet.up.wroc.pl/ kabala/Analizy2017v8.pdf

Kabała C., Musztyfaga E., Gałka B., Łabuńska D., Mańczyńska P., 2016a. Conversion of soil $\mathrm{pH} 1: 2.5 \mathrm{KCl}$ and $1: 2.5 \mathrm{H} 2 \mathrm{O}$ to 1:5 $\mathrm{H}_{2} \mathrm{O}$ - conclusions for soil management, environmental 
monitoring and international soil databases. Polish Journal of Environmental Studies 25(2): 647-653.

Kabała C., Świtoniak M., Charzyński P., 2016b. Correlation between the Polish Soil Classification (2011) and international soil classification system World Reference Base for Soil Resources (2015). Soil Science Annual 67(2): 88-100.

Kacprzak A., Derkowski A., 2007. Cambisols developed from cover-beds in the Pieniny Mts. (southern Poland) and their mineral composition. Catena 71(2): 292-297.

Kalembasa D., Pakula K., Jaremko D., 2011. Sorpcyjne właściwości gleb Wysoczyzny Siedleckiej. Acta Agrophysica 18(2): 311-319. (in Polish with English abstract).

Keesstra S.D., Bouma J., Wallinga J., Tittonell P., Smith P., Cerdà A., Bardgett R.D., 2016. The significance of soils and soil science towards realization of the United Nations Sustainable Development Goals. Soil 2(2): 111.

Klasyfikacja gleb leśnych Polski (Classification of forest soils in Poland), 2000. CILP, Warszawa: 127 pp.

Kobierski M., Kondratowicz-Maciejewska K., Kociniewska K., 2015. Soil quality assessment of Phaeozems and Luvisols from the Kujawy region (Central Poland). Soil Science Annual 66(3): 111-118.

Kowalska J., Kajdas B., Zaleski T., 2017. Variability of morphological, physical and chemical properties of soils derived from carbonate-rich parent material in the Pieniny Mountains (south Poland). Soil Science Annual 68(1): 27-38.

Krupski M., Kabala C., Sady A., Gliński R., Wojcieszak J., 2017. Double-and triple-depth digging and Anthrosol formation in a medieval and modern-era city (Wrocław, SW Poland). Geoarchaeological research on past horticultural practices. Catena 153: 9-20.

Leitgeb E., Reiter R., Englisch M., Schad P., Feger K.H., 2013. Waldböden: Ein Bildatlas der Wichtigsten Bodentypen aus Österreich, Deutschland und der Schweiz. John Wiley \& Sons, Germany: 387 pp.

Lityński T., Jurkowska H., Gorlach E., 1976. Analiza chemiczno-rolnicza. PWN, Warszawa: 178 pp. (in Polish).

Łabaz B., Kabala C., 2016. Human-induced development of mollic and umbric horizons in drained and farmed swampy alluvial soils. Catena 139: 117-126.

Łabaz B., Kabała C., Bogacz A., 2016. Problems of trophic status diagnosis in the forest habitats on former arable alluvial soils. Sylwan 160(8): 684-695 (in Polish with English abstract).

Labaz B., Musztyfaga E., Waroszewski J., Bogacz A., Jezierski P., Kabala C., 2018. Landscape-related transformation and differentiation of Chernozems-Catenary approach in the Silesian Lowland, SW Poland. Catena 161: 63-76.

Maksimow A., Góralski J., 1959. Właściwości sorpcyjne i odczyn gleb. Państwowe Wydaw. Rolnicze i Leśne, Warszawa: $280 \mathrm{pp}$.

Mendyk Ł., Świtoniak M., Bednarek R., Falkowski A., 2015. Genesis and classification of the soils developed from the sediments of the former Oleszek mill pond basin (the Chełmińskie Lakeland, N Poland). Soil Science Annual 66(1): 29-35.

Musielok Ł., Drewnik M., 2016. Quantification of the effects of weathering and pedogenesis in mica schist regolith material (Złote Mountains, Poland) using mass balance analysis. Carpathian Journal of Earth and Environmental Sciences 11(2): $627-637$.
Nemeček J., Macků J., Vokoun J., Vavřiček D., Novák P., 2001. Taxonomický Klasifikační Systém Půd České Republiky. ČZU Praha - VÚMOP Praha, Praha: 152 pp.

Pokojska U., 1986. Rola próchnicy w kształtowaniu odczynu, właściwości buforowych i pojemności jonowymiennej gleb leśnych. Soil Science Annual - Roczniki Gleboznawcze 37(2-3): 249-263 (in Polish with English abstract).

Polish Soil Classification (Systematyka Gleb Polski), 2011. Roczniki Gleboznawcze - Soil Science Annual 62(3): 1-193 (in Polish).

Porębska G., Ostrowska A., Borzyszkowski J., 2008. Changes in the soil sorption complex of forest soils in Poland over the past 27 years. Science of the total environment 399(1-3): 105-112.

Reintam E., Köster T., 2006. The role of chemical indicators to correlate some Estonian soils with WRB and Soil Taxonomy criteria. Geoderma 136: 199-209.

Ross D.S., Matschonat G., Skyllberg U., 2008. Cation exchange in forest soils: the need for a new perspective. European Journal of Soil Science 59(6): 1141-1159.

Schollenberger C.J., Simon R.H., 1945. Determination of exchange capacity and exchangeable bases in soil-ammonium acetate method. Soil Science 59(1): 13-24.

Secu C.V., Patriche C., Vasiliniuc I., 2008. Aspects regarding the correlation of the Romanian Soil Taxonomy System (2003) with WRB (2006), Soil Science 9(3-4): 56-62.

Shi X.Z., Yu D.S., Xu S.X., Warner E.D., Wang H.J., Gong Z.T., 2010. Cross-reference for relating Genetic Soil Classification of China with WRB at different scales. Geoderma 155: 344-350.

Soil Survey Staff, 2014. Keys to Soil Taxonomy, 12th ed. USDANatural Resources Conservation Service, Washington, DC: $245 \mathrm{pp}$.

Steinhardt G.C., Mengel D.B., 1981. Comparison of pH measurement by field and laboratory methods. Communications in Soil Science and Plant Analysis 12(1): 71-78.

Sumner M.E., Miller W.P., 1996. Cation exchange capacity and exchange coefficients. [In:] Sparks D.L. (Ed.) Methods of Soil Analysis, Part 3, SSSA Book Series, Madison, Wisconsin: 1201-1229.

Szewczyk A., Kaniuczak J., Hajduk E., Knap R., 2015. Physical and chemical properties of selected soils from the surroundings of the Magura National Park (southern Poland). Soil Science Annual 66(1): 36-44.

Świtoniak M., 2015. Issues relating to classification of colluvial soils in young morainic areas (Chełmno and Brodnica Lake District, northern Poland). Soil Science Annual 66(2): 5766.

Świtoniak M., Charzyński P. (Eds.), 2018. Soil sequences atlas II. Machina Druku and Nicolaus Copernicus University, Toruń, Poland: 248 pp.

Waroszewski J., Sprafke T., Kabala C., Musztyfaga E., Łabaz B., Woźniczka P., 2018. Aeolian silt contribution to soils on mountain slopes (Mt. Ślęża, southwest Poland). Quaternary Research 89, 3: 702-717.

Weber J., Karczewska A., Drozd J., Licznar M., Licznar S., Jamroz E., Kocowicz A., 2007. Agricultural and ecological aspects of a sandy soil as affected by the application of municipal solid waste composts. Soil Biology and Biochemistry 39(6): 1294-1302.

Received: June 12, 2018

Accepted: October 2, 2018

Associated editor: P. Hulisz 


\section{Współzależności między pH gleby a wysyceniem kationami zasadowymi - wnioski dla polskiej i międzynarodowej klasyfikacji gleb}

Streszczenie: Uwzględniając następujące fakty: (a) pomiar pojemności wymiany kationów oraz wysycenia kompleksu sorpcyjnego kationami zasadowymi jest praktycznie niemożliwy w terenie, co formalnie czyni niemożliwą klasyfikację wielu typów gleb w trakcie prac terenowych, (b) wysycenie kationami zasadowymi jest wyznaczane kilkoma metodami, których wyniki różnią się istotnie, a także (c) wysycenie kationami zasadowymi i pH gleby są istotnie dodatnio skorelowane, sugeruje się, aby wartość $\mathrm{pH}_{\mathrm{w}}$ (mierzona w zawiesinie wody destylowanej/dejonizowanej) zastapiła wysycenie kationami zasadowymi jako kryterium klasyfikacyjne w definicjach poziomów diagnostycznych i jednostek/podjednostek glebowych w Systematyce Gleb Polski oraz w klasyfikacji WRB. Bazując na analizie statystycznej ponad 4500 próbek glebowych, rekomenduje się zastapienie kryterium $50 \%$ wysycenia kationami zasadowymi: wartością $\mathrm{pH}_{\mathrm{w}}<5.5$ dla poziomu umbric i $\mathrm{pH}_{\mathrm{w}} \geq 5.5$ dla poziomu mollic, oraz dla Chernozems, Kastanozems, Phaeozems (bezpośrednio) i Umbrisols (pośrednio). Podobnie, $\mathrm{pH}_{\mathrm{w}}<4.7$ proponuje się dla kwalifikatora Dystric $\mathrm{w}$ glebach mineralnych i odpowiednich grup referencyjnych WRB, oraz odpowiednio $\mathrm{pH}_{\mathrm{w}} \geq 4.7$ dla kwalifikatora Eutric. Rozróżnianie podtypów gleb brunatnych w Systematyce Gleb Polski może bazować na $\mathrm{pH}_{\mathrm{w}} 4.7$ lub 5.0, ale z zastosowaniem innych kryteriów co do zróżnicowania $\mathrm{pH}$ w sekcji kontrolnej. Propozycja zastąpienia wysycenia kationami zasadowymi przez wskaźnik pH odnosi się wyłącznie do systematyki gleb i nie umniejsza znaczenia wskaźnika wysycenia kationami zasadowymi w profesjonalnej charakterystyce gleb.

Słowa kluczowe: wysycenie kationami zasadowymi, pH, klasyfikacja gleb, WRB, Systematyka gleb Polski 